ISSN 1822-8402 EUROPEAN INTEGRATION STUDIES 2014. No. 8

\title{
ETHICAL LEADERSHIP: STUDENT PERCEPTIONS OF EXERCISING ETHICAL INFLUENCE IN ORGANIZATION
}

\author{
Velga Vevere \\ The University College of Economics and Culture, Latvia \\ The University of Latvia \\ Lomonosova 1, korp. 5, Rīgā, LV-1019 Latvija \\ e-mail:velga.vevere@gmail.com
}

cross $^{\text {ref }}$ http://dx.doi.org/10.5755/j01.eis.0.8.6987

Today's rapidly changing economic and social environment requires reconsideration of leadership issues, a special attention paying to ethical issues that are an integral part of socially responsible business. There are numerous studies on the subject matter of ethical leadership but until now the matter of developing business students' ethical leadership competences has been hardly touched. This is one of the gaps to be filled if we want to speak about the Europe of knowledge at all. The purpose of the present study is twofold: to summarize the previous research in the field of ethical leadership and to research Latvian business students' perception of ethical leadership. Hence the tasks of this study are: to conceptualize main notions of the ethical leadership; to disclose the concept of power bases and social influence;) to work out the research design and to perform the survey on student perception of the ethical aspects of exercising influence; to interpret results and work out practical suggestions for teaching business ethics. The primary method used in the present inquiry is quantitative survey applying the Likert scale (the sample of probability is $N=206$ - business students attending classes in business ethics taught by the author of the present paper). The students were asked to put themselves in the shoes of the business organization manager and to decide for themselves what steps they would take in order to influence their subordinates. The results were grouped according to five power bases (coercive power, reward power, legitimate power, expert power, referent power). No form of power is inherently immoral; still some of them (especially related to power and coercion) can be more unethical in certain circumstances. The results of the survey showed that ethical issues of business leadership in general were of no special concern for students, although they recognized some critical aspects and cases of unethical behavior. The results made it possible to work out suggestions how to improve the course plan in business ethics (introducing new aspects related to leadership; including more subject related case study discussions; preparing practical exercises, etc.).

Keywords: business ethics, ethical leadership, ethical influence, coercive power, reward power, legitimate power, expert power, referent power.

\section{Introduction}

Today's rapidly changing economic and social environment requires reconsideration of leadership issues, a special attention paying to ethical issues that are an integral part of socially responsible business. There are numerous studies on the subject matter of ethical leadership but until now the matter of developing business students' ethical leadership competences has been hardly touched. This is one of the gaps to be filled if we want to speak about the Europe of knowledge. The significance of the problem is related to the fact that today's business students are future business leaders, so it is necessary to educate them in ethical issues, in general, and to develop their skills in leading a business organization in ethical way, in particular. To work out the teaching design it is necessary to find out current students' opinion about these issues. The purpose of the present study is twofold: to summarize the previous research in the field of ethical leadership and to research Latvian business students' perception of ethical leadership. Hence the tasks of this study are as following: to conceptualize main notions of the ethical leadership; to disclose the concept of power bases and social influence; to work out the research design and to perform the survey on student perception of the ethical aspects of exercising influence; to interpret results and work out practical suggestions for teaching business ethics. This accounts for the structure of the present paper. It consists of two theoretical parts - the first chapter of the article is devoted to the concept of ethical leadership, where the main stress is placed on the social learning perspective of ethical leadership proposes that leaders influence others via modeling (observational learning, imitation and identification) since this particular approach, in our opinion, allows us to develop a model of ethical leadership starting from the bottom up, i.e., taking into account the particular business situation and ethical organizational culture, and to work out specific criteria for management. The focus of the second chapter is the power/interaction model of the interpersonal influence originally developed by J. R. P. French and B. H. Raven. The social influence was defined as a change in the belief, attitude, or behavior of a person (the target of influence), which results from the action of another person (an influencing agent). Social power was defined as the potential for such influence, the ability of the agent to bring about such change using resources available to him or her. The following three parts are devoted to the empirical research the survey of business students' perception of different power 
(reward, coercive, legitimate, expert, and referential) bases and their ethical implications. The method employed is the quantitative survey of the students of the two Latvian private business schools who attend the course in business ethics; the sample of probability is $\mathrm{N}=206$. The results are depicted in the tables and figures; they are compared and interpreted. In the conclusion the author points out the significant aspects of the ethical leadership, as well as offers the recommendations for further development of the business ethics curriculum.

\section{Concept of Ethical Leadership}

Although ethical issues in business leadership have been a matter of importance for quite a long time period, perspectives taken have been either philosophically grounded, i.e., relying on the general concepts of justice, truthfulness, etc. (Langlois, L., 2008; Painter-Morland, M., Etenbos, R., 2011), or looked at from the solely managerial perspective (i.e., authentic/inauthentic, transformational/transactional leadership styles). Moreover, in many cases there exists a dissociation of ethics from business practices; this leads to perception of moral deliberations as a hindrance on the road to success. (Millar, C., Poole, E., 2011) Still since the task at hand is to create the theoretical background for the empirical research on business students' perception of exercising ethical influence, we will not attempt to give a comprehensive literature overview on the subject of business ethics and leadership; rather we will delineate the main directions and developments pertaining the subject, in order to be able to work out an appropriate survey design and an according model for result analysis.

In order to structure studies on the subject ethical leadership we propose to employ a three-level model of analysis of ethical business leadership developed by Daniel E. Palmer; he distinguishes the following levels: ethics of the leader, the means of ethical leadership, and the heart of leadership. (Palmer, E.P., 2009)

The first level implies focusing upon the ethical behavior of business leaders qua individuals. They are expected to exhibit high personal moral standards and to serve as role models for their followers. It has been noted that those leaders who behave according "high morals" are probably less prone to moral transgressions in their business practices. (Bowie, N. E., 2005; Zaccaro, S. J., at al., 2008) Although most of the researchers stress this relation, a different concern with the first level of analysis is that focusing upon the personal morality of leaders may pose the danger of leading us to hold leaders personally accountable to a higher standard of morality than we do others. (Palmer, D. E., 2009) This can lead to the heightened expectations the leaders are not being able to live up to. In her research on business executives' perception of ethical leadership Catherine Marsh (Marsh, C., 2013) stresses such value perspectives as mindfulness, engagement, authenticity, and sustainment. The value perspective of mindfulness is composed of the valued approaches of ethical leadership: observation, time for reflection, systems thinking, rational process, and dialogue and questioning. The value perspective of engagement, representing involvement in ethical action embraces diversity, cultivates relationships, terminates relationships, and encourages risk taking. Authenticity represents personal integrity, self-knowledge; whereas sustainment is composed of the valued approaches of ethical leadership: no illusions, hope, and holistic approach to work and life.

The second level of analysis concerns the means of ethical leadership. According to Palmer (Palmer, E.P., 2009), one way to look at it would be from the viewpoint of specific actions that are taken in performing leadership functions. Another way would be to view the means of leadership in terms of styles or models of leadership. The latter approach allows better understanding of the diverse actions within the particular leadership model. At the same time, we should admit that none of the leadership styles is inherently moral or immoral, although some of them (for example, those which are orientated towards performance solely, or those exhibiting large power distance tend to discern ethical dimensions - everything goes when the job has to be done). The way how leaders' ethical/ unethical behavior affects their subordinates is being analyzed in various research papers, the attention of investigators mostly is paid to such aspects of leadership as unethical behavior of followers, multifoci social exchange perspective, trickle-down effect of ethical influence, phenomenon of social distance, relationship conflict, leadership of ethics, etc. Let's dwell on these possible outcomes briefly. In choosing models for appropriate behavior, individuals are likely to pay attention to and emulate behaviors from credible and attractive role models. Given their positions in organizations, supervisors are often deemed legitimate models for normative behavior. (Mayer, D. M., et. al., 2012; Ghahroodri, H.K., et al., 2013) Multifoci social exchange perspective presupposes that ethical leaders at different organizational levels impact subordinate behavior in different ways; employees intentionally direct their commitment towards specific ethical leaders depending on their appraisal of those leaders and their relationship on professional and personal levels (Hansen, S.D., et.al., 2013) But there is also empirical evidence that organizational level ethical leadership affects employee behavior through the mediator of supervisory ethical leadership or, in other words, the ethical influence "trickles down" to employees by the way of immediate supervisors. (Mayer, D.M., et al., 2009) The concept of social distance in the ethical leadership literature is being tied up with the phenomenon of influence perception by followers - leaders' unethical decisions are evaluated more harshly in higher social distance; lower social distance between the evaluator and the leader causes the evaluator to consider more the thoughts and motives of the leader and other circumstantial information, which in turn affects the extent to which the leadership behavior is considered ethical. (Tumasjan, A., et al., 2011) Ethical leadership and relationship conflict management - working under ethical leader, employees may become more willing to allow coworkers to express their opinion, avoid personal attacks on coworkers, and demonstrate respect and consideration for coworkers' needs. (Mayer, D. M., et. al., 2012). All the above mention factors make it possible to develop the concept/model of the leadership of ethics (ELI - ethical leadership inventory) consisting of three phases. (Spangenberg, H., Theron, C. C., 2005) The ELI thus interprets leadership as a complex, continuous process expressing itself in an extensive array of inter-dependent behavioral actions. The process essentially entails three sequentially linked phases (a) the development and selling ethical vision for the unit, based on an assessment of internal and external environment of the unit, (b) the preparation of the unit for the implementation of 
the ethical vision, and (c) the bold yet honest implementation of the vision by continually monitoring, revitalizing, fine-tuning and orchestrating a multitude of prerequisites for realizing the ethical unit vision.

The third level of ethical analysis, according to D. E. Palmer (Palmer, D. E., 2009) presupposes a common mission and vision. Viewed from this angle the leadership appeals to two elements: telos, which represents the common good to be sought, and a vision, or projection of how that good will be achieved. If there is no balance between these two elements can lead to the ethical failures in organization. Thus the ethical leadership can fail if the leader's vision is inherently in conflict with the mission of the business or vice versa when the vision is centered upon the mission that is inherently unsupportable. So there exists a close link between good leadership and sustainable business practices (Bowie, N., 2005; Kaptein, M., 1998; Sarwar, C.I., 2013) and in the long run being ethical leads to the ethical organizational culture and to the public and financial success. This concept has been developed by C. E. Harshman and E. F. Harshman (2008), they emphasize four basic factors that influence the leadership style-organizational context, individual properties, situation, and social role taken up by the leader. The phenomenon of ethical/unethical leadership style is being explored by a wide range of theoreticians and practitioners from the viewpoints of general business ethics, as well as from the managerial perspective. It is not our task in the present paper to describe differences between these two approaches; rather we would like to delineate the ethical components of leadership.

It has been admitted in the research literature that transformational and charismatic leaders are thought to be ethical leaders who model ethical conduct (Brown, M. E., Mitchell, M.S., 2010), in sum, they are regarded as authentic leaders (Walumbwa, F.O. et.al., 2008; Yukl, G., 2008; George, B., 2003). The contrast of the transformational as authentic leadership and transactional as inauthentic leadership styles is analyzed by K. S. Groves and M. A. LaRocca (2011) and O.Turunc, M. Celik and I. S. Mert (2013), as well as by M. E. Brown, L. K. Trevino, D. A. Harrison (2005) in their seminal work in the field "Ethical Leadership: A Social learning perspective for construct development and testing" and its companion peace "Ethical leadership: A review and future directions" (Brown, M. E., Trevino, L. K., 2006), the above mentioned articles lays down the basic principles of the new conception of the social learning perspective that entails the construct of ethical leadership. Transformational leadership is defined as a process where leaders and followers engage in a mutual process of raising one another to higher levels morality and motivation. (Turunc et. al., 2013) Transformational leadership includes five leadership dimensions: idealized attributes, idealized behaviors, inspirational motivation, intellectual stimulation, and individualized consideration. Such leaders earn credit and respect from their followers considering their needs above their personal needs, and taking into account moral consequences of their key decisions (Groves, K. S., LaRocca. M. A., 2011). They influence others by developing collective vision and inspiring them to look for a common good, rather than their self-interest. It should be noted thought that in some cases the transformational leadership can exhibit characteristics of unethical behavior as well, for example, if followers are being manipulated into believing in sacrificing their personal interests. At the same time, the ethical leaders can use the transactional-type influence processes such as standard setting, performance appraisal, and rewards and punishments to hold followers accountable for ethical conduct. (Trevino, L. K. et al., 2003) Thus there is only a partial overlapping between transformation and ethical leadership. Transactional leaders, on the other hand, aim at controlling others and supporting the existing status quo in the leader/ follower relation by exercising different forms of power (the question of the power and power bases will be discussed in the next chapter of the present article). M. E. Brown and others have found that ethical leadership is related to these other leader styles and characteristics, but none of these is broad enough to encompass all than an ethical leader is seen to do. They propose to view ethical leadership within a social learning framework. (Brown, M. E. at al, 2005)

A social learning perspective of ethical leadership proposes that leaders influence others via modelling (observational learning, imitation and identification). In our opinion, this construct of ethical leadership is the most fruitful as it allows: (a) to develop a model of ethical leadership starting from the bottom up, i.e., taking into account the particular business situation and ethical organizational culture; (b) to work out specific criteria for management. M. E. Brown and others propose that leaders become attractive, credible, and legitimate ethical role models by engaging in ongoing behaviors that are evaluated by the followers as normatively appropriate. (Ibid.) They have worked out ten-item instrument to measure perceptions of ethical leadership - the Ethical Leadership Scale (ESL), which includes such aspects as: (1) listening to what employees have to say; (2) disciplining employees who violate ethical standards; (3) conducting his/personal life in an ethical manner; (4) having the best interests of employees in mind; (5) making fair and balanced decisions; (6) are trustworthy; (7) discussing business ethics or values with employees; (8) setting the behavioral example; (9) defining success not only by results, but also the way that they are obtained; (10) always asking question "what is the right thing to do?" (Brown, M.E., Trevino L. K., 2003) I sum, the difference of this model from all others lies in the fact that evaluation is being done by followers. They define ethical leadership as the demonstration of normatively appropriate conduct through personal actions and interpersonal relationships, and the promotion of such conduct to followers through two-way communication, reinforcement, and decision-making. (Brown, M. E. et al., 2005)

\section{Power/Interaction Model of Interpersonal Influence}

Forms of power and influence have long been the matters of interest in philosophy, social psychology, management and organizational behavior studies, cultural studies, etc. To illustrate this statement let us mention just one line of reasoning, represented by French social philosopher Michel Foucault whose concern for power is a leading motif in many of his works, but most of all "Discipline and Punish: The Birth of Prison" (Foucault, M., 1995). Here he talks of the body politics (the ways people are being controlled by reducing the distance, almost nullifying their individualities). In the chapter entitled "panopticism," he speaks metaphorically of the way we are controlled by authority: that our respect for 
those in power springs not from the actual strength of authority, but rather from an individual's fear of the authority. The building of Panopticon is a circular building made up of multiple rings of holding cells, one on top of the other. In the center of these rings is a tower, to observe the activity of the prisoners, workers, etc. Each cell is large enough for a single person, and separated from the next by a wall; this way, prisoners cannot see each other, and thus function as individuals. The front of the cell is blocked with bars, so that the prisoner is visible from the tower, and the back of the cell has a window so that the prisoner is illuminated with sunlight and cannot hide. The main thing is that that any prisoner can see the tower, feel it watching him, and know that he is powerless to escape its gaze; but that at the same time, the guard in the tower need not be looking at that exact prisoner. (Ibid.) So the result is the state of anxiety, the state of being permanently watched or supervised (in the management literature it has been called the abusive supervision). C. Anderson and L. Berdhal (2002) define power as the ability to provide or withhold valued resources or administer punishments. The important property of power is that it is contextual, related to a particular relationship in a group. It is interesting, that according to the fore mentioned research that having high power is associated with a higher level of rewards and lower level of threats in the environment and people with higher power tend to be me more approach orientated. (Ibid.) Still it doesn't say a lot about the ethical aspects of leadership, since event he approach orientated bosses are as exposed to inhibition tendencies as lower rank managerial staff. A. H. B. de Hoogh and D. N. den Hartog (2009) speculate on the subject matter of ethics and power, concluding that ethical leadership can be defined as the process of influencing in a socially responsible way the activities of an organized group toward goal achievement. Another topic related to exercising the interpersonal influence. The type of behavior used in an effort to influence the attitudes and behavior of another person is called an influence tactic. (Yukl, G., 2009) These tactics are classified in the following way: proactive (related to the immediate task at hand); impression management (used to influence view targets view the agent); rational persuasion (using logical arguments); appraising (explaining how carrying out a request will benefit the target personally); inspirational appeals (appealing to values and ideals); consultation (encouraging the target to suggest improvements); collaboration ((offering to provide relevant resources and assistance); ingratiation (using praise and flattery); personal appeals (asking for support out of friendship); exchange (offering an incentive); coalition tactics (citing the support of others as reason for target to agree); pressure (making demands or threats). (Ibid.) The influence tactics from the receiver (target) side is being investigated by J. E. Barbuto and G. T. Gifford (2009); they state that influence trigger is to be understood as a target's reaction to an influence of attempt; each time an agent attempts to influence a target, some type of trigger will occur for the target. Still as one of the most successful models for analyzing leaders' influence on their subordinates, as recognized by a number of researchers (Rahim, M.A., 2009; Koslowsky, M., Schwarzwald, J., 2009; Johnson, C.E., 2012) is the one called the power/interaction model of interpersonal influence. This model was created by J. R. P. French and B. H. Raven (1959), later it was developed and diversified in order to adapt to the contemporary business situations (Azoult, L. et al., 2013). The social influence was defined as a change in the belief, attitude, or behavior of a person (the target of influence), which results from the action of another person (an influencing agent). Social power was defined as the potential for such influence, the ability of the agent to bring about such change using resources available to him or her. These resources are represented in six bases of power (Raven, B. H., 2008) Let us characterize each base subsequently. Coercive power is based on a subordinates perception that their supervisor has the ability to punish them if they fail to conform to the influence attempt; in other words, it is a function of the perception of subordinates of the extent to which their supervisors can inflict punishment (firing, suspending, ridiculing, demoting, reprimanding, etc.) for undesired behavior. Reward power is based on the perception of subordinates that their supervisor can reward them for desired behavior; in other words, it is associated with the ability to provide positive inducements for desirable behavior (pay raises, promotions, bonuses, or recognitions). Legitimate power is based on the internalized values of subordinates which dictate that the supervisor has the right to prescribe and control their behavior and they have the obligation to accept the influence; the power is vested in the rights, duties, and responsibilities of the position, not the personal properties of the power holder. Expert power is based on the subordinates belief that that their supervisor has adequate professional experience, training, special expertise, and access to knowledge. Referent power is based on the desire of subordinates to identify and associate with their supervisor; here control is dependent on the supervisor's charisma or personal magnetism to attract subordinates to follow them. Informational power - the supervisor carefully explains to the subordinate how the job should be done differently, the subordinate understands and accepts the reasons and changes his/her behavior. Later on Raven reconceptualized the original taxonomy and proffered model of eleven tactics. Coercion and reward were separated into personal an impersonal; adding personal coercion and personal reward helped to understand why some instances of social influence required surveillance. Legitimate power was differentiated into four tactics, all of which reflected various social norms. The definitions for expertise, reference, and informational tactics remained to their original formulations. It is of a particular interest to know what bases of power strategies are most likely to be effective. A power strategy, which works almost immediately where surveillance is necessary (reward or coercive power) may not be long lasting if the continued surveillance is impossible. If on one hand the reward power ten to lead to greater satisfaction on the part of employees, and thus might increase influence in a broader range of situations, the, on the other hand, the coercive power can be more effective in influencing a subordinate who has jeopardized the success of the overall organization. The manner in which the power strategy is utilized also affects its success or failure. The power/interaction model of interpersonal influence is an attempt how the process operates and the conditions that determine effectiveness and ineffectiveness of social influence. It can be concluded that a leader who is more aware of, either formally or informally, of the various options in social power strategies will be more 
successful and effective. (Raven, B. H., 2008) The question of ethical aspects of leadership remains open as none of all power tactics is inherently ethical or unethical; leaders draw their power from the variety of sources. The morality of the particular power source depends on the ends or goals it serves. Still the power linked to the organizational position (coercion, reward, and legitimate) is more likely to be abused than expert and referent powers. Thus extreme coercion can be devastating to individuals, attacking their dignity and basic beliefs, their moral values. (Johnson, C. E., 2012) Powerful individuals, who fail to master their negative emotions, project them to others. Moreover, these people are more susceptible to judgment biases, namely, they are not interested in how others feel, and thus they are acting on harmful stereotypes; powerful people protect their positions by attacking those they perceive as threats. At the same time having too little power can pose ethical dilemmas. Powerless employees can't achieve serious goals; they don't have any control over their environment. They try to maintain the amount of power they have and take out frustrations on others. Selecting the appropriate tactic is one of the more important choices, and ethical considerations play the central role. According to Johnson there are four most widely used organizational influence strategies: impression management, deception, emotional labor, and the communication of expectations; each of them contain a set of ethical variables. Although being a part of everyday business practices impression management can be perceived as an act of manipulation. Therefore, targets of impression management tactics have an ethical responsibility to ensure that agents aren't unduly or unfairly shaping decisions and outcomes. Deception is defined as knowingly trying to mislead others. In the organizational context deception this most often appears as self-interest and role conflict. Role conflict acts as a stimulus, providing the reason to lie; rewards them provide the motivation to engage in lying. (Johnson, C. E., 2012) It is possible to reduce role conflicts not setting too high expectations and keeping line of communications open in order to resolve possible conflicts. Emotional labor is a special form of image management, more specifically; employees manage their feelings so that they can present the desired bodily and facial displays and hold back their anger contacting customers. This entails its own special set of ethical issues, that is, the private feelings are more or less owned by the company, this can be quite costly emotionally for them and can lead to the total burnout. Communication of expectations - the ethical dilemmas can arise both from too high and too low expectation levels set for employees. Too high level, as we have already said, can lead to lying and hiding truth (no one wants to appear a looser in the eyes of the supervising officer); whereas distrust can create indifferent or even negative attitudes to management and projects a t hand.

Apart from analyzing moral components of leadership in general, it is necessary to turn to ways business students gain their knowledge about business ethics, about real processes within the field - successes and failures. And perhaps the most important question is how to close the gap between general philosophical considerations and real organizational practices. Here we can agree with A. Palma-Angeles (213) that the aim of a Business Ethics course should not be merely presenting ethical theories, principles, and concepts. More than anything it should capacitate students with tools necessary to understand their environment, take on their moral dilemmas, and make ethical decisions. To accomplish this, the course must start with students' experiences and then introduce the theories and concepts as tools for reflection and analysis. As well as teaching business ethics should rely on students' own personal experiences in the beginning in order to graduate to the theoretical level of expertise in the end. M. J. Thomson (2013) stresses that reframing business ethics in the management education curriculum may, for example, challenge the relevance of traditional ethical theories to ethical debate whilst not rejecting their role in the discourse of moral philosophy. Business ethics in its traditional form did not enter mainstream management education, and in its twentieth century format, failed to impact mainstream business education and practice. This leads to the necessity to establish the current status of so-called "ethical consciousness" of business students to develop and introduce new teaching approaches - both technical (based on interactivity) and conceptual (based on modern management and ethical theories). And since today's students are our future leaders their moral standing becomes of a special importance.

These theoretical considerations, two models, i.e., the social learning perspective on ethical leadership and power/ interaction model of interpersonal influence helps us to formulate the research questions for the present investigation, as well as to work out methodology. The research questions are the following:

- What are the most popular leadership styles/power bases in students' perception?

- Are students orientated towards "hard" (coercive, reward) or "soft" (expertise, referent, legitimate) powers?

\section{Method}

Research design. In order to investigate beliefs held by students, we chose a quantitative research design - formalized survey of participants to explore their opinion about optimal ways of exercising ethical influence. Approaching the students involved in under-graduate business ethics courses provided a first-hand account of how they make use of the knowledge and all factors that influence it. Students were approached with the request to be questioned about the leadership styles. The questionnaire was developed on the basis of literature study; it consisted of twenty questions divided into five groups (accordingly 4 questions concerning each of the power bases); questions were presented in the mixed order to get the truthful response from the surveyed. Each question had three possible answers: agree; neither agree, nor disagree; disagree. The actual questioning was performed by the author of the present article; the respondents received all necessary explanations about the purpose of the research.

Sample. Once the research design and interview method were established, it was necessary to make a decision about the sampling unit (a unit of population chosen during the sampling process; the unit should contain one or more elements describing the population). Participants of the survey were chosen according to the principle to include students taking the course in business ethics in two private business schools in the study year of 2013/2014. This procedure can be described as a probability (element) sampling, i.e. single stage procedure where sampling unit contains only one element, 
namely, involvement in the class of business ethics. (Smith and Albaum 2012) Altogether 206 students were surveyed.

Analysis. Results of the semi-structured interviews were assigned values from 1 to 3 on the Lickert scale, accordingly 1 for "disagree" 2 for "neither agree, nor disagree", 3 for "agree". Then a quantitative summary of all results was created. Finally, all results were ranked according to the frequency of mentioning within each of 5 question groups.

\section{Research and discussion}

What are the most popular leadership styles/power bases in students' perception? Are students orientated towards "hard" (coercive, reward) or "soft" (expertise, referent, legitimate) powers?

In order to give the answers to these research questions we added up all positive answers to each of 20 questions, the divided these answers into 5 groups according to which power base the particular answer is alluded. The maximum of possible positive answers within each reference group is 206 x $4=824$ (total number of respondents x number of questions within the category). The results are depicted in the tables 1-5 accordingly. But before turning to discussion of the results, let's dwell briefly on the most characteristic features of the each of power bases one more time, since it is important for making conclusions. Thus the leadership power bases can be described in the following way:

- Reward power depends on being able to assign the value to followers' actions,

- Coercive power is based on penalties or punishments,

- Legitimate power resides in the official and administrative position;

- Expert power is based on the characteristics of the individual;

- Referent (role model) power rests on the admiration one individual holds for another.

The respective choice of the course of actions entails certain ethical consequences as it was described above, some of the leadership modes are more subjected to possible ethical violations, obvious or hidden manipulations by the leaders. Still first of all we have to look at the summary results of the positive answers (in our article we leave aside the neutral and/ or negative responses since our interest lies in the students' preferential power model, the analysis of correlations between different power models is to be undertaken in the next article of the series devoted to teaching business ethics in business school).

Table 1. Sum of students' positive responses to using the reward power

\begin{tabular}{|c|l|c|}
\hline No. & \multicolumn{1}{|c|}{ Question } & $\begin{array}{c}\text { Sum of "agree" } \\
\text { answers }\end{array}$ \\
\hline 1 & Increasing their pay level & 117 \\
\hline 13 & Helping them get a pay increase & 111 \\
\hline 16 & Providing them with special benefits & 96 \\
\hline 17 & Helping them get a promotion & 101 \\
\hline Total & & 425 \\
\hline
\end{tabular}

Source: Author's.

We have to state that the ethical aspects of the reward power are related to the just or unjust distribution of the awards. Students' answers to the questions involving their potential actions within the mode of reward power (pay raise, promotion, etc.) demonstrate that a little bit more than half of them (425 out of 824) are positive. This outcome compelled us to conclude that material or immaterial incentives were not on the top in students' must-do list. In our opinion, this could be explained by two main reasons: first, by the financial and psychological consequences of the recent global economic recession; second, by the fact that students en masse, perhaps due to the lack of experience, didn't believe in the value of investing into the staff development.

Table 2. Sum of students' positive responses to using the coercive power

\begin{tabular}{|c|l|c|}
\hline No. & \multicolumn{1}{|c|}{ Question } & $\begin{array}{c}\text { Sum of "agree" } \\
\text { answers }\end{array}$ \\
\hline 3 & Giving undesirable job assignments & 39 \\
\hline 9 & Making the work difficult for them & 9 \\
\hline 11 & Making things unpleasant here & 3 \\
\hline 12 & Making work distasteful & 4 \\
\hline Total & & 55 \\
\hline
\end{tabular}

Source: Author's.

The use of the coercive power base turned out to be extremely unpopular among the business students, although the distribution of answers among four possibilities were a bit surprising, namely, 39 out of 55 responses stressed the giving undesirable job assignments as the dominant manipulative tool, although the rest of possibilities (i.e., making the work difficult, unpleasant or distasteful) seemed almost the same. We think that the reason could be the unconscious wish of students to look better in their own eyes, as well as in the eyes of the prospective interpreters of the results. More precisely, assigning the hard-to-do or someone-must-to-do jobs could seem less vicious from the psychological viewpoint, namely, this rests on the belief that the final result is what matters and all assignments lead to the accomplishing the task at hand. Moreover, the results demonstrated that students were aware of the possible negative consequences - the excessive use of power by the leaders resulting in the total moral irresponsibility of their employees (no rights to personal opinion, no voice, no responsibility, and no accountability).

Table 3. Sum of students' positive responses to using the legitimate power

\begin{tabular}{|c|l|c|}
\hline No. & \multicolumn{1}{|c|}{ Question } & $\begin{array}{c}\text { Sum of "agree" } \\
\text { answers }\end{array}$ \\
\hline 5 & $\begin{array}{l}\text { Making them feel that they have } \\
\text { commitments to meet }\end{array}$ & 138 \\
\hline 14 & $\begin{array}{l}\text { Giving them feeling that they have } \\
\text { responsibilities to fulfill }\end{array}$ & 196 \\
\hline 18 & $\begin{array}{l}\text { Giving them the feeling that they have } \\
\text { duties to serve }\end{array}$ & 191 \\
\hline 20 & $\begin{array}{l}\text { Making them recognize that they have } \\
\text { tasks to accomplish }\end{array}$ & 198 \\
\hline Total & \multicolumn{2}{|c|}{723} \\
\hline
\end{tabular}

Source: Author's.

The results depicted in the table 3 speak by themselves, i.e., 723 out of 824 positive responses are given to controlling the followers within their professional lives by using the position of the leader. The overwhelming preference for this power 
base could be explained by the fact, that all respondents were students in the program of business administration, i.e., the future managers and/or leaders. At the same time this position could be the source of the ethical manipulations resulting in satisfaction of the leaders' ambitions. On the other hand, this approach could result also in the empowerment of the staff, as they feel their significance.

Table 4. Sum of students' positive responses to using the referent power

\begin{tabular}{|c|l|c|}
\hline No. & \multicolumn{1}{|c|}{ Question } & $\begin{array}{c}\text { Sum of "agree" } \\
\text { answers }\end{array}$ \\
\hline 2 & Making them feel valued & 197 \\
\hline 4 & Making them feel like I approve of them & 139 \\
\hline 6 & Making them feel personally accepted & 172 \\
\hline 7 & Making them feel important & 182 \\
\hline Total & & 690 \\
\hline
\end{tabular}

Source: Author's.

The high level of positive responses to the statements regarding the referent power base (690 out of 824) show that the students as future leaders were aware of the power of encouragement, since employees tend to go an extra mile for the leader who vales them as personalities and professionals. Interestingly enough, one of the statements stand out with its considerably lower level of positive answers, namely, the statement "making them feel like I approve of them" (139 responses out of 690). In our opinion, this could be explained by the predisposition of the students as future leaders not to exhibit their weakness, because the straightforwardly expressed approval might lead to the loss of their authority whereas the stating of their position could be a matter of prime importance for young leaders. Still this mode of power also could be the source of the ethical manipulation, though the milder form of it in comparison with the direct coercion. In this case the leaders should understand his responsibilities even more as they pull the invisible strings and they could appeal to the moral sense and consciousness of their followers.

Table 5. Sum of students' positive responses to using the expert power

\begin{tabular}{|c|l|c|}
\hline No. & \multicolumn{1}{|c|}{ Question } & $\begin{array}{c}\text { Sum of "agree" } \\
\text { answers }\end{array}$ \\
\hline 8 & Giving them good technical suggestions & 188 \\
\hline 10 & Sharing my experience and/or training & 182 \\
\hline 15 & Providing them with job-related advice & 183 \\
\hline 19 & $\begin{array}{l}\text { Providing them with needed technical } \\
\text { knowledge }\end{array}$ & 181 \\
\hline Total & \multicolumn{2}{|c|}{734} \\
\hline
\end{tabular}

Source: Author's.

The expert power alludes to knowledge, skills, education, and certification; as a result employees who are not in positions of authority can be very influential because they possess the valuable information. It is important to take a notice that in contrast to other previously described power bases (the reward, the coercive, the legitimate, the referent ones), the bearers of the expert power could be both - the leaders and the followers. 734 out of 824 positive responses show that the students see here the paths to empower themselves by making themselves irreplaceable as valued employees and unique as business leaders (the one who simultaneously have the administrative power and the expertise in their business realm). Nevertheless, this can entail some moral consequences. In other words, the expert power can be like a double-edged sword - the relationships between the boss and the follower could be quite complicated if the subordinate is more knowledgeable than the supervisor. This could lead either to the suppression of any initiative from below (and that is morally unacceptable) or to the leader's losing the sense of leadership (in some cases it can result in the humiliation of the subordinates, and this is morally unacceptable as well).

The overall picture of positive responses we can see in th figure 1 .

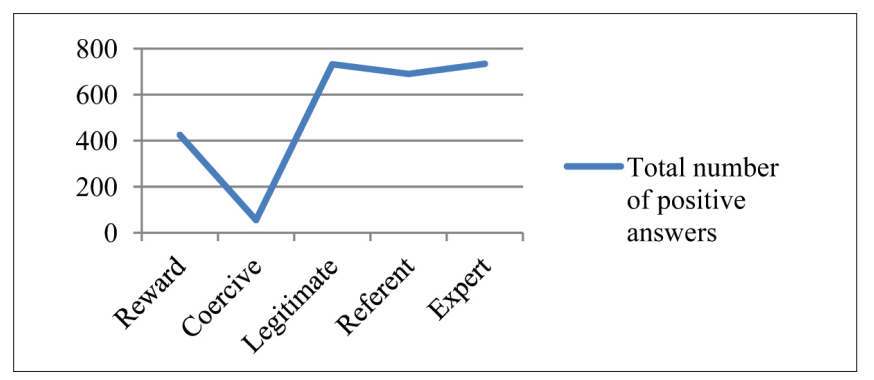

Figure 1. Students' preferences for particular power bases

The graphic demonstrates that among the business students surveyed the most positive responses received the statements referring to the legitimate, the referent and the expert bases, while clearly the least value was assigned to the coercive power base as sometimes necessary short-term solution to everyday business matters, but not serving the goal of the sustainable business development that necessarily involves ethical responsibilities and moral soundness of the leaders. Our research shows that the students are more orientated towards "soft" power modes that rest on mutual relations between the leaders and the subordinates, on the discussion/negotiation culture, on the academic knowledge and professionals skills and competences. The "hard" power mode, on the other hand, is not as popular among the business students; they tend to disregard the reward and/or coercive, the "carrot and/or stick" approach that refers to a policy of offering a combination of rewards and punishment to induce the desired behavior. This could be explained by the students being aware (at least partly) of the ethical dubiousness of being the manipulators as well as of being manipulated by others. Besides that, the survey results show that a special place among students is being assigned to the legitimate or position power; as it was stated above, we believe that the main reason for such phenomenon lies in the fact that all respondents involved in the survey were the business administration students, that is, the future leaders in their own perception, this factor shaped their overall attitude to the proposed statements. We believe also that such distribution of the students' responses was the result of the previous discussions, case study analyses within the study course of business ethics.

\section{Limitations of the Research}

The fact that only those students who were enrolled in course of business ethics and had participated in class discussions on the subject were surveyed set some limitations 
for the research; namely, they probably had some prior theoretical knowledge and emotional disposition to one or another question. Perhaps the distribution of answers would be different if students without any knowledge about ethical leadership would be questioned as well. We can mention another factor that possibly influenced results - the previous job experience as a manager or as an employee, or the lack of it at all. Moreover, some of the students were small business owners, but the questionnaire was not discriminatory (i.e., it didn't contain questions about students' employment), as the result we obtained only general results. Without any doubt, those having had worked in some position would have a different perspective in comparison to those fresh out of school. Despite these limitations, we nevertheless believe that our research was representative (all respondents were first or second year business students) and it has exposed some prevailing tendencies that should be taken into account and thought of when developing the future curriculum for business studies.

\section{Conclusions}

Our research was grounded in two theoretical models: the one of the social learning perspective of ethical leadership developed by M. E. Brown, L.K. Trevino and D. A. Harrison; and the one of the power/interaction model of interpersonal influence conceived by J. R. P. French and B. H. Raven. In our opinion, the combination of those made it possible to create the research design for the investigation of the students' perception of the ethical aspects of leadership. This matter is of the special importance as these students are our future leaders; therefore, their concern for the morality of their actions is the basis of the sustainable business development. Of course, not all of them will be our future CEOs or business managers, but the knowledge of the leadership ethics would be beneficial for any carrier in business. None of the described leadership modes (i.e., based on the reward, the coercive, the legitimate, the expert and the referential power) is a priori ethical or unethical, each of them presupposes some level of influencing others. Still, the so-called "hard" powers are more apt to ethical transgressions in comparison with the "soft" ones. The students should recognize the pluses and minuses, ethical risks of each of the power modes. The survey results prove that the students questioned have more positive attitude towards the expert, the referent and the legitimate powers, the ones that are being recognized as elements of the transformational leadership. One of the reasons for such orientation is the fact that all participants of the survey had previously participated in the classroom discussions and case study analyses during the lectures on business ethics. This outcome proves that the discussions, as well as readings of the theoretical literature and the research articles can influence the students' opinion about the leadership ethics and can form their moral stance regarding certain business issues. At the same time we can speak of the limitations of the current research since all students were informed about the basic ethical concepts and dilemmas. Perhaps, the result would be different if the respondents had been chosen from the student groups not learning business ethics. The second aspect to be considered here: the respondents had different professional backgrounds - some of them were fresh out of the high school and didn't have any working experience, while others had worked or even owned the small businesses. Still, we believe that this survey exposed the general tendencies in students' perception of the modes of exercising ethical influence in business organizations. Thus we can conclude that the curriculum of business ethics should include the aspects of the ethical leadership, as well as of the ethical followership, and the ethical conflict management. The classes should contain group discussions, simulations of unethical behavior situations, etc. Moreover, the curricula of other subjects, such as marketing, management, personnel management, social psychology and others should contain at least some aspects of business ethics.

\section{References}

Anderson, C., Berdahl, J. L., 2002. The Experience of Power: Examining the Effects of Power on Approach and Inhibition Tendencies. Journal of Personality and Social Psychology, 83(6), pp. 1362-1377. http://dx.doi. org/10.1037/0022-3514.83.6.1362

Auzoult, L., Hardy-Massard, S., Gangloff, B., 2013. Causal Attributions of Compliance or Rebellion According to the Raven's Bases of Power. Cognition. Brain. Behavior. An Interdisciplinary Journal, 17(3), pp. 237-48.

Barbuto, J. E. jr., Gifford, G.T., 20009. Influence triggers and compliance: A discussion of the effects of power, motivation, resistance, and antecedents. Power and Interdependence in Organizations, Cambridge University Press, pp. 262-80.

Bowie N. E ., 2005. Expanding the horizons of leadership. The Quest for Moral Leaders. Essays on Leadership Ethics, Edward Elgar, pp. 144-60.

Brown, M. E., Mitchell, M.S., 2010. Ethical and Unethical Leadership: Exploring New Avenues for Future Research. Business Ethic Quarterly, 20(4), pp. 583-616. http://dx.doi.org/10.5840/beq201020439

Brown, M. E., Trevino, L. K., 2006. Ethical leadership: A review and future directions. The Leadership Quarterly, 17, pp. 595-616. http://dx.doi.org/10.1016/j. leaqua.2006.10.004

Brown, M. E., Trevino, L. K., Harrison, D. A., 2005. Ethical Leadership: A Social learning perspective for construct development and testing. Organizational Behavior and Human Decision Processes, 97, pp. 117-134. http:// dx.doi.org/10.1016/j.obhdp.2005.03.002

De Hoogh, A., H., B., Den Hartog, D., N., 2009. Ethical Leadership: The Socially Responsible Use of Power. Power and Interdependence in Organizations, Cambridge University Press, pp. 338-54.

Foucault, M., 1995. Discipline and Punish: The Birth of the Prison, Vintage Books.

French, J. R. P., Raven, B.H., 1959. The bases of social power. Studies in Social Power, Institute for Social Researc, pp. 150-67.

George, B., 2003. Authentic Leadership. Rediscovering the Secrets to Creating Lasting Value, Jossey-Bass.

Ghahroodri, H. K., Ghazal, M. Z., Ghorban, Z. S., 2013. Examining ethical leadership and its impact on the followers' behavioral outcomes. Asian Social Science, 
9(3), pp. 91-96.

Groves, K. S., LaRocca, M.A., 2011. An Empirical Study of Leader Ethical Values, Transformational and Transactional Leadership, an Follower Attitudes Towards Corporate Social Responsibility. Journal of Business Ethics, 103, pp. 511-28. http://dx.doi.org/10.1007/ s10551-011-0877-y

Hansen, S. D., Alge, B.J., Brown, M. E., Jackson, C. L., Dunford, B. B., 2013. Ethical leadership: assessing the value of multifoci social exchange perspective. Business Ethics, 115, pp. 435-49. http://dx.doi.org/10.1007/ s10551-012-1408-1

Harshman, C. E., Harshman, E. F., 2008. The Gordian Knot of Ethics: Understanding Leadership Effectiveness and Ethical Behavior. Journal of Business Ethics, 78, pp. 175-92. http://dx.doi.org/10.1007/s10551-006-9318-8

Heinemann, P., 2007. Power Bases and Informational Influence Strategies. A Behavioral Study on the Use of Management Accounting Information, Deutscher Universitäts-Verlag.

Johnson, C. E., 2012. Organizational Ethics. A Practical Approach, Sage.

Kaptein, M., 1998. Ethics Management. Auditing and Developing the Ethical Content of Organizations, Kluwer Academic Publishers.

Koslowsky, M., Schwarzwald, J., 2009. Power tactics preference in organizations: Individual and situational factors, Power and Interdependence in Organizations. Cambridge University Press, pp. 244-61.

Langlois, L., 2011. The Anatomy of Ethical Leadership, AU Press.

Marsh, C., 2013. Business Executives' Perceptions of Ethical Leadership and Its Development. Journal of Business Ethics, 114, pp. 565-82. http://dx.doi.org/10.1007/ s10551-012-1366-7

Mayer, D. M., Aquino, K., Greenbaum, R. L., Kuenzi, M., 2012. Who displays ethical leadership, and why does it matter? An examination of antecedents and consequences of ethical leadership. Academy of Management Journal, 55(1), pp. 151-171. http://dx.doi.org/10.5465/ amj.2008.0276

Mayer, D. M., Kuenzi, M., Greenbaum, R. L., Bardes, M., Salvador, R., 2009. How does ethical leadership flow? Test of a trickle-down model. Organizational Behavior and Human Decision Processes, 108, pp. 1-13. http:// dx.doi.org/10.1016/j.obhdp.2008.04.002

Millar, C., Poole, E., 2011. Ethical Leadership. Global Challenges and Perspectives, Palgrave Macmillan.

Painter-Morland, M., Etenbos, R., eds., 2011. Business Ethics and Continental Philosophy, Cambridge University Press. http://dx.doi.org/10.1017/ CBO9781139013338

Palma-Angeles, A., 2013. Teaching Business Ethics: Challenges and Responses. Dimensions of Teaching Business Ethics in Asia, Springer, pp. 121-32. http:// dx.doi.org/10.1007/978-3-642-36022-0_9

Palmer D. E., 2009. Business Leadership: Three levels of ethical analysis. Journal of Business Ethics, 88, pp. 52536. http://dx.doi.org/10.1007/s10551-009-0117-x

Rahim, M. A., 2009. Bases of leader power and effectiveness. Power and Interdependence in Organizations, Cambridge University Press, pp. 224-43. http://dx.doi.org/10.1017/CBO9780511626562.015

Raven, B. H., 2008. The Bases of Power and the Power/ Interaction Model of Interpersonal Influence. Analyses of Social Issues and Public Policy, 8(1), pp. 1-22. http:// dx.doi.org/10.1111/j.1530-2415.2008.00159.x

Sarwar, C. I., 2013. Future of Ethically Effective Leadership. Journal of Business Ethics, 113, pp. 81-9. htaparttp:// dx.doi.org/10.1007/s10551-012-1283-9

Smith, S. M., Albaum, G.S., 2012. Basic Marketing Research. Handbook for Research Professionals, vol.1., Qualtrics Labs Inc.

Spangenberg, H., Theron, C. C., 2005. Promoting ethical follower behavior through leadership of ethics: The development of the ethical leadership inventory (ELI). South African Journal of Business management, 36(2), pp. 1-18.

Thompson, M. J., 2013. Reframing Business Ethics in the Management Education Curriculum. Dimensions of Teaching Business Ethics in Asia, Springer, pp. 133-46. http://dx.doi.org/10.1007/978-3-642-36022-0_10

Trevino, L. K., Brown, M., Hartman, L. P., 2003. A qualitative investigation of perceived executive ethical leadership: Perceptions from inside and outside the executive suite. Human Relations, 55, pp. 5-37. http:// dx.doi.org/10.1177/0018726703056001448

Tumasjan, A., Strobel, M., Welpe, I., 2011. Ethical leadership evaluations after moral transgression: social distance makes the difference. Journal of Business Ethics, 99, pp. 609-22. http://dx.doi.org/10.1007/s10551010-0671-2

Turunc, O., Celik, M., Mert, I. S., 2013. The Impact of Leadership Styles on Ethical Behavior. Journal of Academic Research in Economics, 5(1), pp. 60-85.

Walumbwa, F. O., Avolio, B. J., Gardner, W. L., Wernsing, T. S., Peterson, S. J., 2008. Authentic Leadership: Development and validation of a theory-based measure. Journal of Management, 35, pp. 89-126.

Yukl, G., 2008. Leadership in Organizations, Pearson Education.

Yukl, G., 2009. Power and the Interpersonal Influence of Leaders. Power and Interdependence in Organizations, Cambridge University Press, pp. 207-21. http://dx.doi. org/10.1017/CBO9780511626562.014

Zaccaro, S. J., Gulick, L.M., Khare, V. P., 2008. Personality and Leadership. Leadership at the Crossroads, Praeger Publishers, pp. 13-29.

The article has been reviewed. Received in April, 2014; accepted in June, 2014. 